Body Build.-The better-nourished Pakem villagers had greater mean weight, height, weight/height ratios $(\mathrm{W} / \mathrm{H})$, and arm circumferences than the other villagers. The differences between them in body build are illustrated in Fig. 2, which shows the mean $\mathrm{W} / \mathrm{H}$ ratios in relation to age and sex in each village.*

\section{Discussion}

The mean systolic, but not diastolic, pressures recorded in this study are lower than those found in Western peoples - Hamilton et al. (1954)-and in several Asian and Pacific peoples (Lovell et al., 1960). Low blood-pressures have been recorded in semi-starvation (Keys et al., 1950) and other poorly nourished groups-for example, Chinese rickshaw men (Lowenstein, 1954)-but whether this is due to lowered calorie intakes only or in part to lowered protein intakes is not known. In these Javanese villagers, with very low intakes of both, differences in protein intake do not seem to influence blood-pressure.

The relation of blood-pressure to age varies in different peoples. In Western peoples the mean systolic and diastolic pressures rise with age, while in several other populations rises have been found to be slight or absent; these include poor Chinese (Kean and Hammill, 1949), East Africans (Donnison, 1929), Gilbertese (Maddocks, 1961), and New Guinea Highlanders (Whyte, 1958). In these Javanese villagers systolic pressures rise with age. It seems, therefore, that while malnutrition may be associated with relatively low systolic pressure, it does not prevent the rise with age which is found in better-nourished peoples. However, renal disease was not eliminated in the Javanese as a possible cause of this rise (cf. Stirling, 1960).

*Detailed measurements available on request. (Author's present address, 5 Lamington Street, Deakin, Canberra, A.C.T., Australia.)

\section{Summary}

Blood-pressures and measures of body build were recorded from three Javanese villages where there was general undernutrition. Rice was the staple foodstuff in one, and cassava in two ; protein intakes were appreciably better in the former.

Blood-pressure levels were similar in each village. Systolic pressures (but not diastolic) were low compared with other populations and systolic pressures rose with age.

In these undernourished subjects, protein deficiency does not seem to be the cause of lowered systolic pressure, and low calorie and protein intakes do not prevent rising systolic pressures with age.

I am indebted to Professor R. R. H. Lovell, University of Melbourne Department of Medicine, and his staff, and to Miss B. Laby, University of Melbourne Department of Statistics, for guidance and assistance in the preparation of this report.

\section{REPERENCES}

Bailey, K. V. (1960). Rural Nutrition Studies in Indonesia (Thesis), University of Melbourne.

- (1961). Trop. geogr. Med., 13, 216, 233.

Donnison, C. P. (1929). Lancet, 1, 6.

Hamilton, M., Pickering, G. W., Roberts, J. A. F., and Sowry, G. S. C. (1954). Clin. Sci., 13, 11.

Kean, B. H., and Hammill, J. F. (1949). Arch. intern. Med., 83, 355 .

Keys, A., Brozek, J., Henschel, A., Mickelsen, O., Taylor, H. L., et al. (1950). The Biology of Human Starvation. University of Minnesota Press, Minneapolis.

Lowenstein, F. W. (1954). Amer. Heart J., 47, 874.

Lovell, R. R. H., Maddocks, I., and Rogerson, G. W. (1960). Aust. Ann. Med., 9, 4.

Maddocks, I. (1961). Lancet, 2, 396.

Stirling, G. A. (1960). Brit. med. J., 1, 1173.

Whyte, H. M. (1958). Aust. Ann. Med., 7, 36.

\title{
GUANETHIDINE IN THE TREATMENT OF HYPERTENSION
}

\section{CLIFTON P. LOWTHER, M.B., M.R.C.P.G. M.R.C.P.Ed. \\ Senior Medical Registrar, Western General Hospital, Edinburgh}

This paper describes the treatment of 75 patients with guanethidine over periods ranging from 3 to 36 months, with an average duration of 24 months. Sixty-seven have been treated for more than one year, 58 for more than 18 months, and 40 for more than two years. The indications for treatment, selection of patients, measurement of blood-pressure, and classification of results have been similar to those previously described in relation to other drugs (Lowther and Turner, 1960). Forty-one of these patients had been treated with various other preparations before guanethidine was given; the remaining 34 were treated with guanethidine from the outset.

The assessment of the drug has been based solely on its effect on blood-pressure and on the incidence of tolerance and side-effects. Benefits such as the regression of retinopathy or of ventricular hypertrophy are secondary to the fall in blood-pressure, however produced, and not directly attributable to any particular drug.

\section{Material and Methods}

Clinical Features.-Only those patients have been treated who, in addition to high resting diastolic pressures, showed
BY

\section{RICHARD W. D. TURNER, O.B.E., M.A., M.D. F.R.C.P., F.R.C.P.Ed.}

Senior Lecturer, Department of Medicine, University of Edinburgh; Physician, Western General Hospital, Edinburgh

objective evidence of secondary changes in the fundi or heart.

Forty patients were male and 35 female. The average age was 54 years: 10 were under 40 and 14 more than 60 . Clinical details are given in Table I, which shows that these features indicate a fair cross-section of patients with severe hypertensive disease. Retinal changes were classified for convenience according to the criteria of Keith. Wagener,

\begin{tabular}{|c|c|c|c|c|c|}
\hline $\begin{array}{l}\text { Method of } \\
\text { presentation }\end{array}$ & \multicolumn{2}{|c|}{$\begin{array}{l}\text { Left ventricular failure } \\
\text { Cerebrovascular accide } \\
\text { Headache } \\
\text { Disturbance of vision } \\
\text { Routine examination } \\
\text { Miscellaneous ... }\end{array}$} & $\begin{array}{l}e \\
\text { ent } \\
\cdots \\
\cdots \\
\cdots\end{array}$ & $\begin{array}{l}\cdots \\
\cdots \\
\cdots \\
\cdots\end{array}$ & $\begin{array}{c}\text { No. of Cases } \\
17(23 \%) \\
14(19 \%) \\
17(23 \%) \\
10(13 \%) \\
11(15 \%) \\
6(7 \%)\end{array}$ \\
\hline $\begin{array}{l}\text { Resting diastolic } \\
\text { blood-pressure } \\
\text { (mm. Hg) }\end{array}$ & $\begin{cases}150+ & \ldots \\
130-149 & \ldots \\
110-129 & \ldots\end{cases}$ & $\begin{array}{l}\cdots \\
\cdots\end{array}$ & $\begin{array}{l}\cdots \\
\cdots\end{array}$ & $\begin{array}{l}\cdots \\
\cdots \\
\cdots\end{array}$ & $\begin{array}{l}11(15 \%) \\
39(52 \%) \\
25(33 \%)\end{array}$ \\
\hline Retinal changes & $\left\{\begin{array}{cc}\text { Grade } & 4 \\
\ddot{ } & 3 \\
\ddot{\prime} & 2\end{array}\right.$ & $\begin{array}{l}\cdots \\
\cdots \\
\cdots\end{array}$ & $\begin{array}{l}\ldots \\
\cdots \\
\cdots\end{array}$ & $\begin{array}{l}\cdots \\
\cdots \\
\cdots\end{array}$ & $\begin{array}{l}8(11 \%) \\
27(36 \%) \\
38(51 \%) \\
2(2 \%)\end{array}$ \\
\hline $\begin{array}{l}\text { Left ventricular } \\
\text { hypertrophy (E.C.G.) }\end{array}$ & $\begin{cases}\text { Present } & \ldots \\
\text { Absent } & \cdots\end{cases}$ & . & 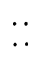 & . & $\begin{array}{l}72 \\
3\end{array}(4 \%)$ \\
\hline Renal function & $\left\{\begin{array}{l}\text { Impaired } \\
\text { Renal failure } \\
\text { Normal .. }\end{array}\right.$ & $\begin{array}{l}\cdots \\
\cdots\end{array}$ & $\begin{array}{l}\cdots \\
\cdots\end{array}$ & $\begin{array}{l}\cdots \\
\cdots\end{array}$ & $\begin{array}{l}13(17 \%) \\
4(5 \%) \\
58(78 \%)\end{array}$ \\
\hline
\end{tabular}


and Barker (1939), although this classification has disadvantages, as previously discussed (Turner, 1959). Criteria for the E.C.G. diagnosis of left ventricular hypertrophy were those recommended by Sokolow and Lyon (1949). Recently these have been modified according to the recommendations of Simonson (1961). Renal failure denotes a blood urea above $50 \mathrm{mg} . / 100 \mathrm{ml}$. Impaired renal function denotes abnormal values for endogenous creatinine clearance or phenolsulphonphthalein excretion but with a normal blood-urea level.

Recording of Blood-pressure.-The blood-pressure was recorded by trained technicians after the fourth consecutive inflation of the cuff. Each reading represents the mean of several measurements taken at intervals. Pressures were recorded in the lying position and again after the patient had been standing for two minutes. In some cases they were repeated after exercise. The "resting" pressures used as baselines for the assessment of results were those recorded as above after the patient had been resting quietly in the wards for a few days and during the period of preliminary investigation.

\section{Dosage and Administration}

The initial dose of guanethidine was usually $10 \mathrm{mg}$. given twice daily after meals. Increments of 5-10 mg. to each total daily dose were usually made on every third day. The drug was given in divided doses rather than in the single daily dose usually recommended, because it seemed likely that on a single dose, unless cumulative, there must be a daily peak and trough of pressure and that smoother control would be achieved with some reduction in the early morning hypotensive period, which is of such frequent occurrence on this treatment.

The daily dose varied between 10 and $225 \mathrm{mg}$., with a mean of $55 \mathrm{mg}$. Most patients required between 20 and $100 \mathrm{mg}$., and only eight had more than $100 \mathrm{mg}$./day. Four patients could not tolerate the initial dosage and maintained good control on only $10 \mathrm{mg}$./day, although they were no less severely hypertensive than the others.

In 42 patients it was necessary to add an oral diuretic in order to obtain or maintain control over the blood-pressure. In seven cases this was given from the outset, usually because of the presence of papilloedema or pulmonary oedema, when it was thought advisable to achieve rapid control over the blood-pressure. In the remaining 35 cases the addition of an oral diuretic was made when it became clear that treatment with guanethidine alone was unsatisfactory. In most cases this was due to the severity of sideeffects, but in a few there were other reasons, such as the development of oedema or failure to gain control over the blood-pressure even with large doses of guanethidine.

\section{Aims of Treatment}

The usual aim of treatment, as in our previous studies of antihypertensive drugs, was to reduce the standing diastolic pressure to as near normal levels as could be achieved without undue side-effects. Only the fall in blood-pressure has been considered in classifying results of treatment. A "good" result signifies a reduction of blood-pressure of $30 /$ $20 \mathrm{~mm}$. $\mathrm{Hg}$ and a fall in the diastolic pressure to below $100 \mathrm{~mm}$. Hg. A " fair" result signifies a fall of $30 / 20 \mathrm{~mm}$. $\mathrm{Hg}$ with a diastolic pressure remaining between 100 and $110 \mathrm{~mm}$. Hg. A " poor" result denotes failure to achieve a significant fall.

In grading results as good or fair a sharp line of demarcation must inevitably be drawn for purposes of analysis, but it will be appreciated that at varying times during treatment some patients will fall on one side of the line and at other times on the other side. In practice, therefore, if the criteria for inclusion in any grade are maintained for $80 \%$ of the period, the patient has been placed in that grade when classifying the final results, so that our conclusions reflect the effect of therapy throughout the period of treatment rather than only at the end.

In 10 cases no attempt was made to produce normal pressures because of the known presence of cerebral or coronary vascular disease or of impaired renal function, and it was felt undesirable to risk any reduction in blood flow to these vital areas. In such cases the standing diastolic pressure was usually maintained at about 100 to 110 $\mathrm{mm}$. $\mathrm{Hg}$, and the result was recorded as "good" because failure to reduce the blood-pressure to normal levels could not be attributed to inadequacy of the drug.

\section{Results}

The results of treatment are shown in Table II. Although only the standing pressure has been used in classifying results the lying pressure has also shown a limited reduction, usually of the order of $50 \%$ of the fall in standing pressure.

Fifteen patients failed to respond to treatment, the majority having to stop the drug altogether. In 13 cases this was due to intolerable side-effects, usually in the form of prolonged dizziness, diarrhoea, or frequency of micturition, and in one case severe nasal congestion. Two patients developed tolerance to such a degree that the dose required to maintain control resulted in side-effects which eventually enforced stopping the drug.

It was notable that, of the nine patients in whom sideeffects led to cessation of treatment, control was poor in five and only fair in four at the time when treatment had to be abandoned. It cannot be said that these patients were having pressures forced down in order to achieve theoretically "good" results, and it is noteworthy that in this group the average daily dose was not above $30 \mathrm{mg}$.

Table III shows the relative severity of the clinical features in good and fair results in 60 cases. It can be seen that there is no important difference between the two groups in respect of these clinical features, and thus there is no indication that good results have chiefly been obtained among the milder hypertensive patients.

\begin{tabular}{ll|l|l|l|l}
\multicolumn{6}{c}{ TABLE II.-Results of Treatment (75 Cases) } \\
\hline $\begin{array}{l}\text { Result } \ldots \\
\text { No. of cases }\end{array}$ & $\cdots$ & $\begin{array}{c}\text { Good } \\
30(40 \%)\end{array}$ & $\begin{array}{c}\text { Fair } \\
30(40 \%)\end{array}$ & $\begin{array}{c}\text { Poor } \\
6(8 \%)\end{array}$ & $\begin{array}{c}\text { Treatment Stopped } \\
9(12 \%)\end{array}$ \\
\hline
\end{tabular}

TABLE III.-Relative Severity of Clinical Features in Good and Fair Results in 60 Cases

\begin{tabular}{|c|c|c|c|c|c|}
\hline Result & $\begin{array}{c}\text { No. } \\
\text { in } \\
\text { Group }\end{array}$ & $\begin{array}{c}\text { Resting } \\
\text { Diastolic. B.P. } \\
>130 \mathrm{~mm} . \mathrm{Hg}\end{array}$ & $\begin{array}{c}\text { Retinopathy } \\
\text { Grades } \\
3 \text { or } 4\end{array}$ & \begin{tabular}{|c|} 
Severe Left \\
Ventricular \\
Hypertrophy
\end{tabular} & $\begin{array}{l}\text { Renal } \\
\text { Impair- } \\
\text { ment }\end{array}$ \\
\hline air & $\begin{array}{l}30 \\
30\end{array}$ & $\begin{array}{l}53 \% \\
47 \%\end{array}$ & $40 \%$ & $\begin{array}{l}66 \% \\
72 \%\end{array}$ & $13 \%$ \\
\hline
\end{tabular}

It is important to emphasize that, although $80 \%$ of patients were classified as having good or fair control of their blood-pressure, there were unsatisfactory features in many of the cases. These can be classified as follows: $(a)$ variability of response, $(b)$ necessity for the addition of oral diuretics, $(c)$ need for antidotes, $(d)$ development of tolerance, and $(e)$ incidence of side-effects.

\section{Variability of Response}

It is well known that daily and even hourly variations in blood-pressure occur in both normal and bypertensive 
subjects, and in our experience variations are no less in patients under treatment with anti-hypertensive drugs. However, this particular difficulty has been less with guanethidine than with bretylium (Lowther and Turner, 1960). Nevertheless, there were some patients with morning hypotension in whom pressures subsequently rose to unsatisfactory levels during the day (Fig. 1).
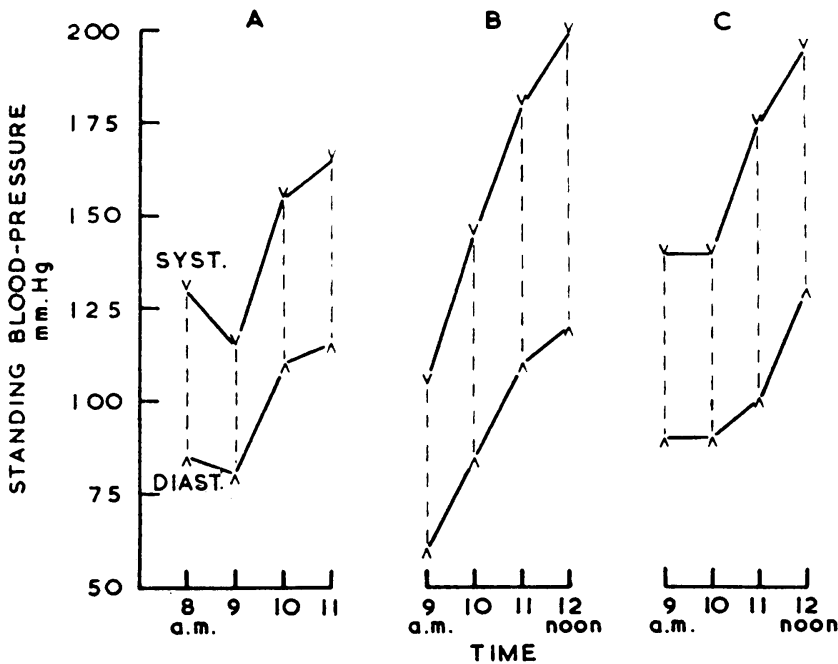

Fig. 1.--Morning hypotension in three patients (A, B, C) taking guanethidine.

\section{Necessity for Oral Diuretics}

The results reported here have not all been maintained with guanethidine alone but in $56 \%$ of cases only with the assistance of oral diuretics. In the earlier part of the series this consisted of $75 \mathrm{mg}$. of hydrochlorothiazide a day and latterly of $100 \mathrm{mg}$. of chlorthalidone on alternate days. In seven cases this addition was made from the outset, as mentioned above, on account of the severity of the patient's condition. Consequently in these cases no assessment can be made of the influence of guanethidine alone. In the remainder the diuretic was usually added when side-effects prevented an increase in the dose of guanethidine.

The effect of adding an oral diuretic in this way has been assessed, the patients falling into three groups. In 11 cases a reduction in the dose of guanethidine was possible and permitted the maintenance of a good result with fewer or less severe side-effects. In nine cases results were converted to more favourable grades but no reduction in the dose of guanethidine was possible. In the remaining 15 cases it could not be shown that the addition of an oral diuretic produced any measurable effect on the bloodpressure.

We have found it necessary to give potassium supplements in only the few patients who had severe renal damage, and we are satisfied that the common practice of giving potassium to all patients under treatment for hypertension with small doses of an oral diuretic is unnecessary. However, in those who have been inadequately assessed it is possible that symptoms of hypokalaemia may bring to light previously unsuspected renal disease or possibly an adrenal tumour (Conn's syndrome).

\section{Antidotes}

The commonest antidote used has been a small dose of a ganglion-blocking drug for the control of diarrhoea. We have used pempidine for this purpose in a dose of 2.5$15 \mathrm{mg}$. daily. In many cases a daily dose of $2.5 \mathrm{mg}$. was sufficient and even apt to produce constipation, a symptom familiar to those previously treated with ganglion-blocking drugs. Pempidine was usually sufficient at least to space out the attacks of diarrhoea, but in view of the explosive and socially embarrassing nature of the attacks codeine phosphate was sometimes added.

Nocturnal frequency of micturition was another undesirable side-effect, and sometimes responded to propantheline ("probanthine") and at other times to pempidine.

As already mentioned, potassium salts were given only in the presence of renal disease or renal failure.

The addition of an oral diuretic has been classified as adjuvant and not antidotal therapy, although in some cases the indication was the occurrence of side-effects, and it was hoped that the reduction in the dose of guanethidine permitted by the addition of an oral diuretic would diminish their severity.

\section{Tolerance}

The term "tolerance" requires definition in this context. Strictly speaking, once the blood-pressure has been reduced and maintained at the required level, any subsequent increase in dosage which is necessary to keep it there may be termed "tolerance." Some workers regard even such a small increase in the dose of guanethidine as $10 \mathrm{mg}$. a day as constituting tolerance. Certainly it is usual for a small increase to be required at the first out-patient attendance after discharge from the ward and return to a normal domestic and working environment, but such initial increases are unimportant.

By important tolerance we imply that, having gained initial control over the blood-pressure, a steady increase in the dose is required in order to maintain such control if, indeed, it can be maintained at all. Such tolerance occurred in eight patients of this series. In five of these a steady increase was necessary from the outset in order to maintain an initially good result. In the remaining three, however, periods of steady control for 6,7 , and 14 months elapsed before any increase was required.

Increments have been considerable and averaged more than double the initial controlling dose, but in all cases adequate control over the blood-pressure has been maintained, although successive increments have usually led to exacerbation of side-effects.

Important tolerance has thus been infrequent leading to only short periods of loss of control, usually with subsequent return or increase in side-effects when dosage was adjusted upwards. Nevertheless, the fact that tolerance ozcurred at all has meant that it has not been possible to allow long intervals between out-patient attendances.

\section{Side-effects}

Table IV shows the incidence of side-effects. The majority of patients experienced one or more of them, and a few unfortunate individuals had as many as six different reactions. Since it is often stated that side-effects seem to diminish as time passes, a further estimate of the incidence was made in 53 patients who had received continuous treatment with guanethidine for 18 months. The incidence was certainly rather lower, as can be seen from Table IV, but it was still far from insignificant. It should also be remembered that all those with severe side-effects stopped treatment in the early stages and consequently do not appear in the figures at 18 months.

Dizziness. - This was one of the most common complaints and tended chiefly to occur shortly after rising in the morning. Its duration varied from a few minutes to an hour or more and was usually aggravated by exertion. This complaint is usually associated with postural hypo- 
tension, but, as already noted, may be followed by a rise in blood-pressure to undesirable levels later in the day. It was originally hoped that guanethidine, with its long duration of action and relatively smooth absorption and excretion, would be free from the disadvantage of a bloodpressure trough. In fact, owing to these very attributes hypotensive troughs may be prolonged and alarming.

\begin{tabular}{|c|c|c|c|c|}
\hline & \multicolumn{2}{|c|}{ At 6 Months ( 75 Cases) } & \multicolumn{2}{|c|}{ At 18 Months ( 53 Cases) } \\
\hline & No. & $\%$ & No. & $\%$ \\
\hline 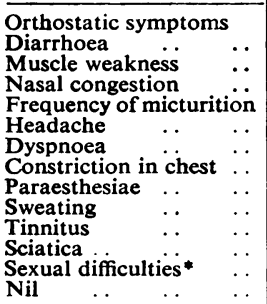 & $\begin{array}{r}61 \\
45 \\
32 \\
24 \\
21 \\
23 \\
13 \\
19 \\
6 \\
5 \\
6 \\
4 \\
4 \\
0\end{array}$ & $\begin{array}{c}81 \\
61 \\
40 \\
35 \\
30 \\
30 \\
19 \\
14 \\
9 \\
7 \\
9 \\
6 \\
17 * \\
0\end{array}$ & $\begin{array}{r}29 \\
20 \\
31 \\
11 \\
11 \\
10 \\
5 \\
5 \\
3 \\
2 \\
1 \\
1 \\
6 \\
2\end{array}$ & $\begin{array}{r}55 \\
38 \\
57 \\
21 \\
21 \\
19 \\
9 \\
9 \\
6 \\
4 \\
2 \\
2 \\
25^{*} \\
4\end{array}$ \\
\hline
\end{tabular}

A 37-year-old man with diastolic hypertension, retinopathy, and left ventricular hypertrophy was given an initial dose of $20 \mathrm{mg}$. of guanethidine a day; this was slowly increased to $60 \mathrm{mg}$. a day over the next eight days without appreciable effect on the pressure. There then followed a fall of standing diastolic pressure to $65-80 \mathrm{~mm}$. $\mathrm{Hg}$, which persisted when the dose was first cut over the next four days to $30 \mathrm{mg}$. a day for five days and thereafter, when no treatment whatever was given for a further eight days (Fig. 2).

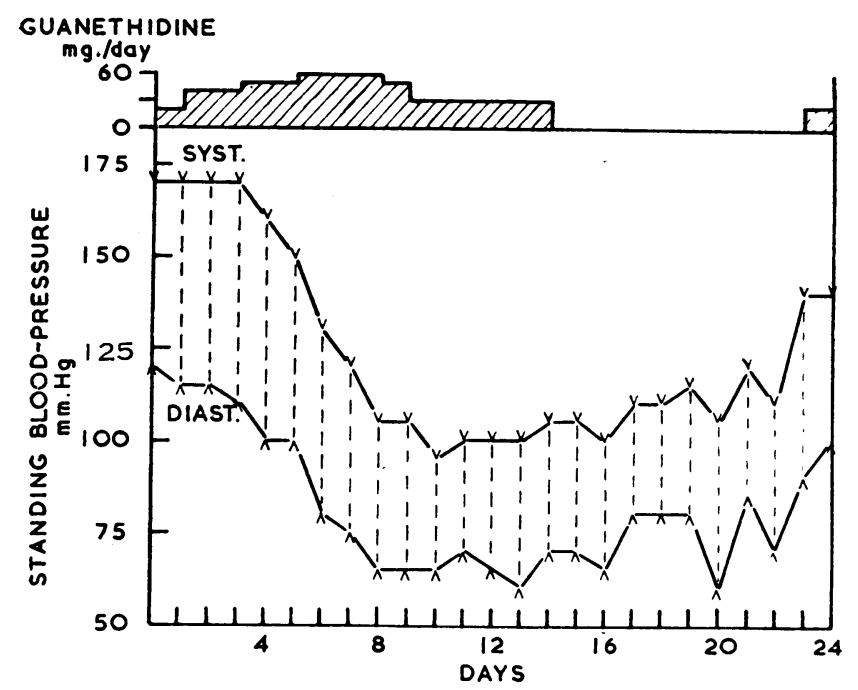

Fig. 2.-Prolonged hypotension on guanethidine.

Muscular Weakness.-This has been another disabling complaint, particularly noticeable in the morning. Walking or repetitive movement such as climbing stairs, ironing clothes, or lifting items on to a shelf became progressively more difficult until it was necessary to rest. On occasion such weakness was associated with pain in the affected muscles or with shaking of the limbs after exertion.

Fall in Blood-pressure After Exertion.-If pressures are recorded not only on standing but after ordinary exercise such as walking or hurrying upstairs, there is a considerable additional fall in most cases. However, in our experience actual syncope has not occurred in patients on guanethidine, and spontaneous complaints of more than mild dizziness have been infrequent. In order to assess the importance of this effect during long-term treatment, pressures were recorded in 30 patients before, immediately after, and one hour after climbing a flight of stairs. In all except one instance the diastolic pressure fell from levels of 90-130 to $70-95 \mathrm{~mm}$. Hg. It was noteworthy that there was relatively less change in the systolic pressure. This, then, would appear to be a useful additional effect of the drug in patients who are up and about, provided there are no side-effects.

Diarrhoea.-This has replaced constipation as the bowel disorder associated with the treatment of hypertension, but it is less frequent and appears to be more acceptable to the patient. It is not so much the frequency of bowel motions as the unpredictable and explosive character of the complaint which has necessitated the addition of an antidote in some cases or made it a reason for withdrawal of the drug. One of our patients who was a butler found that the serving of a four-course meal was a hazardous procedure which he could not be sure of completing uninterruptedly or without precipitate withdrawal from the scene. Housewives were nervous of keeping social engagements. This symptom, as in the case of morning dizziness, often persisted even on a stabilized dose of guanethidine, and if it did disappear an increase in dosage usually brought it back.

Headache.-Headache tended to occur in some patients in the early weeks of treatment, but it was never of sufficient frequency or severity to require reduction in the dose of guanethidine, and usually responded to a simple analgesic. The pain was commonly related to the back of the head and neck, and corresponds to the "nape pain" described by other observers.

Frequency of Micturition.-Frequency was noted mainly at night and the patient often had to rise two to five times, which is a considerable disadvantage, especially in winter It occurred as often in females as in males, was unrelated to infection or previous disease of the urinary tract, and usually could be controlled by the use of a small dose of propantheline or pempidine. It can be attributed to the overaction of the parasympathetic nervous supply to the bladder.

Dyspnoea.-A complaint of breathlessness on mild exertion was made by a few patients but was not usually severe or persistent. It was unaccompanied by evidence of cardiac failure and may possibly be attributable to the increased work of breathing associated with muscular weakness. In two cases dyspnoea was possibly related to fluid retention, but our information on this point is inadequate.

Fluid Retention.-In view of the fact that fluid retention with oedema definitely occurred in a few cases, we decided to record the weight of 30 patients at each out-patient visit. Five showed an increase in weight of 5 to $8 \mathrm{lb}$. (2.3 to $3.6 \mathrm{~kg}$.), and it amounted to $14 \mathrm{lb} .(7.7 \mathrm{~kg}$.) in two. Two of this group had renal impairment and two complained of increased exertional dyspnoea. In all cases the increase in weight was controlled by the addition of an oral diuretic.

Constriction or Paraesthesiae in the Chest.-These complaints usually occurred together and were not closely related to effort. There was no evidence of underlying ischaemic heart disease. Although such symptoms were difficult to analyse, they have occurred too frequently to be ignored.

Sexual Disturbance.-So far as is known sexual difficulties were confined to male patients. Impotence was an occasional complaint, but the principal manifestation was failure of ejaculation. As in patients after undergoing lumbar dorsal sympathectomy, this can be attributed to failure of constriction of the internal vesical sphincter, with 
consequent passage of semen into the bladder. This pattern of disturbance was of importance only when a family was desired and was less distressing than the impotence associated with ganglion-blocking drugs. Its incidence has probably been under-assessed, as not all patients were closely questioned in this regard.

"Sciatic" Pain.-Four patients complained of pain in the distribution of the sciatic nerve, but there was no limitation of straight-leg raising or any changes in the reflexes. Possibly this was merely a variant of the muscular pains referred to above. There was no relation to changes in blood-pressure.

Parotid Pain.-This was a frequent complaint in patients treated with bretylium, but it has not in our experience been attributable to guanethidine. However, it is emphasized that parotid pain may persist for two years or more after treatment with bretylium has been stopped and therefore may be present in patients who have changed over to guanethidine.

Nasal Congestion.-This complaint was severe in only one patient, who had to abandon treatment with guanethidine for this reason. In other cases nasal congestion diminished in severity after the first few weeks.

Tinnitus and Sweating.-These complaints were transient minor occurrences which did not merit treatment.

\section{Discussion}

Initial reports have been encouraging, and there can be no question that the introduction of guanethidine is an advance in the management of patients with hypertension. However, there are a number of practical difficulties in long-term management in relation to the development of late tolerance, the persistence of side-effects, and the need for adjuvants and antidotes.

In this study we have endeavoured to find out whether, after initial assessment in hospital, it is possible to maintain an adequate reduction in pressure on a long-term outpatient basis without undue side-effects.

In general our results are similar to others reported, so far as ability to lower blood-pressure is concerned, but in our experience such results can be achieved in the majority of patients only by the addition of adjuvants or antidotes. We are in agreement that noteworthy tolerance is infrequent, but the fact that it does occur means that patients must be kept under regular supervision on this account too.

In order to try to assess the value of guanethidine alone, this drug has initially been given by itself in most cases and an oral diuretic has been added only when it was difficult to lower the blood-pressure sufficiently. If this could not be done without troublesome side-effects we have settled for a "fair" result; that is, as regards the level of bloodpressure achieved.

The variable incidences of side-effects which have been reported (Page et al., 1961 ; Leishman et al., 1961 ; Eagan and Orgain, 1961 ; Fife et al., 1962) are probably related to three factors: variations in (1) the type of patient treated, (2) the aims of treatment as regards the degree of bloodpressure reduction to be achieved, and (3) the method of eliciting the occurrence of side-effects.

1. It is essential that all papers. should give details not only of the height of the blood-pressure before treatment but of the objective changes present in the fundi, heart, and kidneys.

2. It has been suggested that the incidence of side-effects from guanethidine may be minimized if the physician is satisfied with only a moderate degree of reduction in bloodpressure ; but there is, in fact, no agreement on the degree of reduction which is necessary to achieve the three main objects of treatment: relief of symptoms, reduction in mortality, and prevention or postponement of the complications of hypertensive disease. Under these circumstances it would seem reasonable to aim at physiological levels without undue side-effects. Actually, in our series a good result was not achieved by a higher dosage or at the expense of a greater incidence of side-effects, as can be seen from Table V. Side-effects in the good group might have been less frequent had we been satisfied with a smaller reduction in pressure, but it is quite clear that the incidence of sideeffects with guanethidine is considerable, even in those in whom only a moderate fall in pressure is achieved.

\begin{tabular}{|c|c|c|c|c|c|c|c|c|}
\hline Result & $\begin{array}{c}\text { No. } \\
\text { in } \\
\text { Group }\end{array}$ & $\begin{array}{c}\text { Average } \\
\text { Daily } \\
\text { Dose }\end{array}$ & $\begin{array}{c}\text { Morn- } \\
\text { ing } \\
\text { Dizzi- } \\
\text { ness }\end{array}$ & $\begin{array}{l}\text { Diar- } \\
\text { rhoea }\end{array}$ & $\begin{array}{c}\text { Mus- } \\
\text { cular } \\
\text { Weak- } \\
\text { ness }\end{array}$ & $\begin{array}{c}\text { Nasal } \\
\text { Con- } \\
\text { gestion }\end{array}$ & $\underset{\text { ache }}{\text { Head- }}$ & $\begin{array}{l}\text { Fre- } \\
\text { quency } \\
\text { of } \\
\text { Mic- } \\
\text { turition }\end{array}$ \\
\hline $\begin{array}{l}\text { Good } \\
\text { Fair }\end{array}$ & $\begin{array}{l}30 \\
30\end{array}$ & $\begin{array}{l}52 \mathrm{mg} . \\
64,,\end{array}$ & $\begin{array}{l}77 \% \\
93 \%\end{array}$ & $63 \%$ & $\begin{array}{l}57 \% \\
60 \%\end{array}$ & $23 \%$ & $23 \%$ & $23 \%$ \\
\hline
\end{tabular}

3. We are convinced that unless a questionary is used the normal loyalties of patient to doctor will result in an optimistic statement on the attributes of the drug. Furthermore, it is noticeable that with persistence of side-effects there is a tendency for them to become absorbed into everyday life, and inquiries framed in such general terms as "Are you feeling well ?" are answered in the affirmative by patients who, on subsequent questioning, state that they often fear to keep social engagements because of explosive diarrhoea or that they are in the habit of sitting down for half an hour or more in the morning to allow dizziness or weakness to pass off.

It could be argued that postural symptoms are not, strictly speaking, side-effects of the drug but rather vagaries of the desired effect. However, morning dizziness is a very troublesome complaint and often cannot be avoided if adequate control of the blood-pressure is to be maintained during the rest of the day. This action is more severe with guanethidine than with other anti-hypertensive drugs, and a preparation which has this effect cannot be regarded as more than partially satisfactory. It is also noteworthy that side-effects are noticed by those who have not previously experienced the ill effects of parasympathetic blockade. With all subjective manifestations a double-blind placebocontrolled trial would be ideal, but there are ethical difficulties as regards this in patients with severe hypertensive disease and in need of optimal control over the bloodpressure. Finally, an important practical point to emphasize is that side-effects can be diminished by making only gradual increments in dosage.

\section{Conclusion}

Guanethidine is enjoying a prestige which is based more on freedom from the unpleasant side-effects of parasympathetic blockade common to all ganglion-blocking drugs than on greater ease and efficiency in controlling the blood-pressure.

It cannot be regarded as a very satisfactory drug, because the majority of patients require not only an adjuvant to enhance its effect or to permit a smaller dose but also an antidote either to the side-effects of guanethidine itself or to the adjuvant used, so that most individuals are taking two or three different drugs. 
Close observation and attention to detail are necessary, and are time-consuming to both patient and doctor; there is still, in fact, a considerable price to pay for health. Nevertheless, guanethidine, usually in combination with an oral diuretic, is probably at present the treatment of choice for the majority of patients with severe hypertensive disease.

\section{Summary}

After preliminary assessment in hospital, 75 out-patients with moderate or severe hypertensive disease have been treated with guanethidine for periods up to three years.

An adequate fall in blood-pressure has been maintained in $80 \%$ of these patients throughout the period of observation, but in only half of them could the standing diastolic pressure be maintained at less than $100 \mathrm{~mm}$. $\mathrm{Hg}$.

In order to achieve these results more than half of the patients required the addition of oral diuretics and others were given pempidine, codeine, propantheline, or potassium salts to alleviate side-effects.

Side-effects were frequent but less troublesome than with any previous drug; they included morning dizziness or weakness, diarrhoea, frequency of micturition, and exertional dyspnoea. Variations of blood-pressure throughout the day and prolonged periods of hypotension were also encountered. Tolerance occurred in $10 \%$ of patients.

It is concluded that guanethidine in combination with an oral diuretic is better than previously available drugs for the long-term treatment of severe hypertension. It has, however, a number of disadvantages.

\section{Addendum}

Since the submission of this paper additional information bearing on the efficiency of guanethidine has become avail- able. Of the original 75 patients, three moved away and no uniform follow-up has been possible, and two died, leaving a total of 70 about whom a further statement can be made.

Twenty-one $(30 \%)$ stopped treatment, in most cases because side-effects became too troublesome and more promising drugs were available. Of the remaining 49 who are still on treatment, 24 have now been treated with guanethidine for three or more years and 39 have been treated for two years or more. The results in these 49 patients, by the criteria adopted above, are as follows: good, $28(40 \%)$; fair, $15(21 \%)$; and poor, $6(9 \%)$.

Thus at the end of a long period of treatment worth-while results-that is, good or fair-are still maintained in $61 \%$ of our patients. During the increased period of follow-up late tolerance has appeared in only one additional patient and the average dose-level has remained almost unchanged. As is obvious, it is those patients least troubled by sideeffects who have been able to continue taking the drug. These results continue to justify our conclusion expressed in the terminal paragraph of the Summary.

\section{REFERENCES}

Eagan, J. T., and Orgain, E. S. (1961). J. Amer. med. Ass., 175,

Fife, R., Moran, F., and Prineas, J. (1962). Scot. med. J., 7, 516.

Keith, N. M., Wagener, H. P., and Barker, N. W. (1939). Amer. J. med. Sci., 197, 332 .

Leishman, A. W. D., Matthews, H. L., and Smith, A. J. (1961). Lancet, 2.4.

Lowther, C. P. and Turner, R. W. D. (1960). Brit. med. J., 2, 1049. Page, I. H., Hurley, R. E., and Duston, H. P. (1961). J. Amer. med.

Ass., i75, 543.
Simonson, E. (196i). Differentiation Between Normal and Abnormal in Electrocardiography. Mosby, St. Louis.
ingention

Sokolow, M., and Lyon, T. P. (1949). Amer. Heart J., 37, 161.

Turner, R. W. D. (1959). Lancet, 1, 897, 953.

\title{
METHYLDOPA AND HYDROCHLOROTHIAZIDE COMPARED WITH RESERPINE AND HYDROCHLOROTHIAZIDE IN HYPERTENSION
}

BY

\author{
T. M. AGNEW, M.B., Ch.B., M.R.A.C.P. \\ J. D. K. NORTH, D.Phil., M.B., M.R.C.P., F.R.A.C.P. \\ Medical Unit, Auckland Hospital, Auckland, New Zealand
}

R. O. H. IRVINE, M.D., M.R.C.P., M.R.A.C.P.

Reserpine and other rauwolfia alkaloids in combination with oral diuretics of the thiazide group are widely used in the treatment of patients with moderate hypertension. Reserpine causes drowsiness and reduction in mental alertness; hence this drug in combination is not the ideal treatment for symptomless patients who require hypotensive therapy.

Methyldopa lowers blood-pressure more effectively than either chlorothiazide or reserpine; patients who respond satisfactorily find treatment easy to tolerate (Irvine et al., 1962 ; Dollery and Harington, 1962). Some patients find difficulty with the large number of tablets that are necessary, and minor side-effects, including dryness of the mouth and drowsiness, are still present. It seemed possible that a combination of methyldopa and hydrochlorothiazide might prove a better treatment for patients with moderate hypertensive disease. It was decided to compare these two drugs with a combination of reserpine and hydrochlorothiazide in a double-blind trial.

\section{Method}

Eighteen patients with high resting blood-pressure (9 males, 9 females) were selected; their ages ranged from
33 to 70 years. In seven there was an additional feature such as angina, previous hypertensive heart failure, or a cerebral vascular accident. All patients had hypertensive changes in the vessels of the retina; no patient had haemorrhages or exudates. Patients already on hypotensive therapy had their treatment stopped three weeks before entering the trial.

Patients attended the hypertension clinic between 11 a.m. and 1 p.m. Blood-pressures were recorded every 20 minutes for seven readings, with the patient recumbent after the first and every third reading. The blood-pressure was measured by the method recommended by the Committee for the Standardization of Blood-pressure Readings (1939). One doctor asked about side-effects at each visit.

Investigations at the beginning and end of the trial comprised haemoglobin, leucocyte count, blood urea, liver-function tests, chest $x$-ray examination,. and electrocardiogram.

Identical capsules were supplied containing: (a) placebo powder ; (b) methyldopa, $250 \mathrm{mg}$. ; (c) methyldopa, $250 \mathrm{mg}$., and hydrochlorothiazide, $15 \mathrm{mg}$. ; (d) reserpine, $0.167 \mathrm{mg}$., and hydrochlorothiazide, $15 \mathrm{mg}$. 